\title{
L-Alanine Production from Glucose Fermentation by Hyperthermophilic Members of the Domains Bacteria and Archaea: a Remnant of an Ancestral Metabolism?
}

\author{
GILLES RAVOT, ${ }^{1}$ BERNARD OLLIVIER, ${ }^{1 *}$ MARIE-LAURE FARDEAU, ${ }^{1}$ BHARAT K. C. PATEL, ${ }^{2}$ \\ KATHY T. ANDREWS, ${ }^{2}$ MICHEL MAGOT, ${ }^{3}$ AND JEAN-LOUIS GARCIA ${ }^{1}$ \\ Laboratoire ORSTOM de Microbiologie des Anaérobies, Université de Provence, 13288 Marseille Cedex 9, ${ }^{1}$ and Sanofi Recherche, \\ Unité de Microbiologie, BP 137, 31676 Labège Cedex, ${ }^{3}$ France, and School of Biomolecular and Biomedical Sciences, \\ Griffith University, Nathan 4111, Brisbane, Australia ${ }^{2}$
}

Received 6 February 1996/Accepted 17 April 1996

\begin{abstract}
New members of the order Thermotogales were isolated from nonvolcanically heated geothermal environments, including oil fields and waters of the Great Artesian Basin of Australia, thereby extending their known habitats, previously recognized primarily as volcanic. The hyperthermophilic and thermophilic members of Thermotogales of volcanic origin, together with the recently described nonvolcanic species of this order and three new isolates described in this paper, were all found to produce L-alanine from glucose fermentation, in addition to acetate, lactate, $\mathrm{CO}_{2}$ and $\mathrm{H}_{2}$. L-Alanine production from glucose is a trait in common with Pyrococcus furiosus and Thermococcus profundus. We propose that L-alanine production from sugar fermentation be regarded as an ancestral metabolic characteristic.
\end{abstract}

Members of the order Thermotogales were first found in natural ecosystems associated with active volcanism $(14,20)$. Recently, the range of their known habitat was extended to nonvolcanically heated geothermal environments such as oil fields and subsurface aquifers $(2,10,15,21)$. In order to improve our knowledge of the biodiversity of the Thermotogales, we conducted studies aimed at isolating new strains from such environments. Three new strains were isolated from oil fields and the Great Artesian Basin of Australia. They were phylogenetically placed as members of the Thermotogales (Fig. 1) and designated Thermotoga strain SEBR 7054, Thermotoga strain SEBR 2665, and Fervidobacterium gondwanense $\mathrm{AB} 39^{\mathrm{T}}$. Their isolation indicates that there is greater phylogenetic diversity and distribution of the Thermotogales than was previously recognized (11). Interestingly, our screening did not record the presence of Fervidobacterium species in oil fields and conversely did not record the presence of Thermotoga species in the artesian waters of Australia, though the genera were reported to coexist in volcanic hot springs (11). This distribution of Thermotogales genera is intriguing and may perhaps be due to the absence of elemental sulfur in nonvolcanic geothermal environments; elemental sulfur may serve as a common electron acceptor for growth in volcanic environments $(3,18)$. However, the growth of the Thermotogales in nonvolcanic environments could also result from an adaptive fermentative process.

During our studies of glucose-grown cultures of members of the Thermotogales, not only did we detect acetate, lactate, $\mathrm{CO}_{2}$, and $\mathrm{H}_{2}$ as fermentation end products, as already reported by other researchers (11), but we also observed an unidentified compound. This, together with our inability to calculate accu-

\footnotetext{
* Corresponding author. Mailing address: Laboratoire ORSTOM de Microbiologie des Anaérobies, Université de Provence, CESB/ ESIL case 925, 163 av. de Luminy, 13288 Marseille Cedex 9, France. Phone: 33.91.82.85.76. Fax: 33.91.82.85.70. Electronic mail address: garcia@orstom.esil.univ-mrs.fr.
}

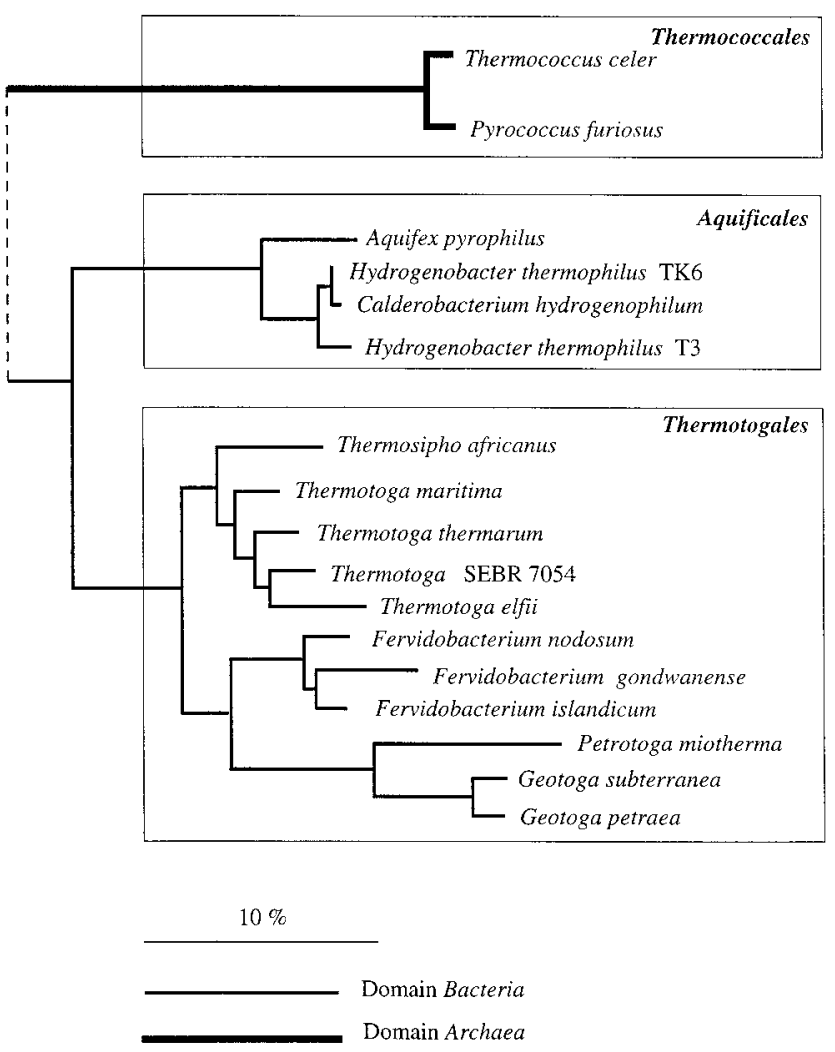

FIG. 1. Dendrogram, based on $16 \mathrm{~S}$ rRNA gene sequence analysis, showing the phylogenetic positions of two new members $(F$. gondwanense and Thermotoga strain SEBR 7054) among the Thermotogales and related bacteria. The sequences used in the analysis were obtained from the Ribosomal Database Project, version 4.1, and from the GenBank database (for Hydrogenobacter thermophilus [Z30214], Calderobacterium hydrogenophilum [Z30242], and Hydrogenobacter strain TS3 [Z30189]). The sequences of Thermotoga strain SEBR 7054 and $T$. profundus are unpublished. Bars indicate evolutionary distance. 
TABLE 1. Acetate and L-alanine production from glucose metabolism by members of the order Thermotogales in the absence or presence of thiosulfate ${ }^{a}$

\begin{tabular}{|c|c|c|c|c|c|c|c|c|c|}
\hline \multirow{2}{*}{ Species or strain ${ }^{b}$} & \multirow{2}{*}{$\begin{array}{l}\text { Growth } \\
\text { condition }^{c}\end{array}$} & \multirow{2}{*}{$\mathrm{OD}_{580}{ }^{d}$} & \multirow{2}{*}{$\begin{array}{l}\text { Amt of glucose } \\
\text { consumed }(\mathrm{mmol})\end{array}$} & \multicolumn{4}{|c|}{ Amt of product $(\mathrm{mmol})^{e}$} & \multicolumn{2}{|c|}{ Ratio } \\
\hline & & & & Acetate & L-Alanine & $\mathrm{H}_{2}$ & $\mathrm{H}_{2} \mathrm{~S}$ & Acetate/Glc & Alanine/Glc \\
\hline \multicolumn{10}{|l|}{ Group I } \\
\hline \multirow{2}{*}{ F. islandicum ${ }^{f}$} & Glc & 0.84 & 14.20 & 6.25 & 3.98 & 21.58 & ND & 0.44 & 0.28 \\
\hline & Glc + thio & 0.96 & 16.20 & 20.25 & 1.22 & ND & 34.02 & 1.25 & 0.08 \\
\hline \multirow[t]{2}{*}{ T. africanus } & Glc & 0.29 & 7.20 & 7.92 & 3.74 & 16.77 & ND & 1.10 & 0.52 \\
\hline & $\mathrm{Glc}+$ thio & 0.36 & 7.70 & 12.40 & 0.00 & ND & 14.55 & 1.61 & 0.00 \\
\hline \multirow[t]{2}{*}{ T. elfii } & Glc & 0.10 & 2.75 & 3.49 & 1.05 & 7.70 & ND & 1.27 & 0.38 \\
\hline & $\mathrm{Glc}+$ thio & 0.30 & 8.15 & 12.63 & 0.41 & ND & 14.55 & 1.55 & 0.05 \\
\hline \multirow{2}{*}{ Thermotoga strain SEBR 7054} & Glc & 0.30 & 8.60 & 4.49 & 1.71 & 29.03 & ND & 0.52 & 0.20 \\
\hline & Glc + thio & 0.91 & 14.39 & 19.70 & 1.06 & 2.29 & 15.08 & 1.37 & 0.07 \\
\hline \multicolumn{10}{|l|}{ Group II } \\
\hline \multirow{2}{*}{ T. maritima } & Glc & 0.28 & 13.70 & 15.62 & 0.69 & 36.09 & ND & 1.14 & 0.05 \\
\hline & Glc + thio & 0.73 & 13.55 & 15.99 & 0.81 & 4.02 & 14.45 & 1.18 & 0.06 \\
\hline \multirow[t]{2}{*}{ T. neapolitana } & Glc & 0.57 & 14.00 & 18.27 & 0.87 & 31.67 & ND & 1.30 & 0.06 \\
\hline & $\mathrm{Glc}+$ thio & 0.94 & 13.90 & 16.12 & 0.60 & 16.07 & 7.39 & 1.16 & 0.04 \\
\hline \multirow[t]{2}{*}{ Thermotoga strain SEBR 2665} & Glc & 0.61 & 12.20 & 15.74 & 0.61 & 33.63 & ND & 1.29 & 0.05 \\
\hline & $\mathrm{Glc}+$ thio & 1.11 & 15.50 & 19.22 & 0.51 & 1.23 & 18.77 & 1.24 & 0.03 \\
\hline
\end{tabular}

${ }^{a}$ Type cultures including T. maritima, T. neapolitana, T. africanus, and F. islandicum were obtained from the Deutsche Sammlung von Mikroorganismen, Fervidobacterium nodosum was purchased from the American Type Culture Collection, and Thermotoga elfii was from our culture collection. They all were grown on a glucose-based medium (16) but the concentration of both yeast extract and bio-Trypcase was decreased to $1 \mathrm{~g} \cdot$ liter ${ }^{-1}$. Fermentation end products were analyzed as described previously (15), and L-alanine was measured by high-pressure liquid chromatography (12).

${ }^{b}$ Group I, strains which produced more than $0.2 \mathrm{~mol}$ of L-alanine per mol of glucose consumed; group II, strains which produced less than 0.2 mol of L-alanine per mol of glucose consumed.

${ }^{c}$ Glc, glucose; thio, thiosulfate $(20 \mathrm{mM})$.

${ }^{d} \mathrm{OD}_{580}$, optical density at $580 \mathrm{~nm}$. Optical densities of control cultures were subtracted.

${ }^{e} \mathrm{ND}$, not detected.

${ }^{f} F$. nodosum and $F$. gondwanense also produced L-alanine from glucose fermentation.

rate carbon recoveries and oxidation-reduction balances from the analyzed data, indicated that an end product was still unaccounted for. This compound was later identified as L-alanine. The amount of L-alanine produced per mole of glucose consumed permitted us to divide the tested Thermotogales into two broad groups (Table 1). Thermophiles within group I-viz., Fervidobacterium islandicum, Thermosipho africanus, Thermotoga elfii, and Thermotoga strain SEBR 7054-produced more than 0.2 mol of L-alanine per mol of glucose, whereas hyperthermophiles of group II-viz., Thermotoga neapolitana, Thermotoga maritima, and the thermophile Thermotoga strain SEBR 2665-produced less than $0.2 \mathrm{~mol}$ of L-alanine per mol of glucose consumed.

Our studies further indicated that several Thermotoga isolates from oil fields, including $T$. elfii (15) and Thermotoga strain SEBR 7054, utilized thiosulfate but not sulfur as an electron acceptor. In contrast, all isolates from volcanic hot springs utilized thiosulfate or sulfur except Thermotoga thermarum, which is currently not reported to use sulfur compounds as electron acceptors (11). The addition of thiosulfate to the carbohydrate-containing growth medium is known to improve the growth rate and cell yields of the tested Thermotogales (16). Data in Table 1 provide further evidence that the use of thiosulfate as an electron acceptor changed the endproduct profile of glucose metabolism by the thermophiles $F$. islandicum, T. africanus, T. elfii, and Thermotoga strain SEBR 7054. For both groups I and II, the addition of thiosulfate reduced the $\mathrm{H}_{2}$ concentration with a concomitant increase in $\mathrm{H}_{2} \mathrm{~S}$ concentration (Table 1). However, the L-alanine concen- tration decreased drastically and the acetate concentration increased for members of group I when thiosulfate was added. A similar behavior was described for Pyrococcus furiosus grown in the presence of elemental sulfur (8). On the other hand, in group II, there was no significant change in L-alanine and acetate production when thiosulfate was added, thus indicating a possible involvement of the oxidative phosphorylation process in glucose metabolism. The reason for the much stronger effect of thiosulfate on glucose metabolism in members of group I than group II could be related to the different $\mathrm{H}_{2}$ sensitivities that members of each group have $(1,6)$.

Phylogenetic studies, determination of physiological properties, and sequence comparisons of ferredoxins suggested that T. maritima (domain Bacteria, order Thermotogales) was closely related to members of the domain Archaea and in particular to $P$. furiosus (4). Both $P$. furiosus and Thermococcus profundus, which belong to the order Thermococcales, one of the deepest branches within the domain Archaea, have been reported to produce L-alanine from carbohydrate fermentation $(8,9)$. Our findings provide further evidence that the Thermotogales, also one of the deepest branches within the domain Bacteria, are closely related to the Thermococcales (Fig. 1). Therefore, Lalanine production can be regarded as an ancestral metabolism. Both T. maritima and $P$. furiosus are known to ferment glucose via the Embden-Meyerhof pathway $(7,19)$. In $P$. furiosus, L-alanine production results from alanine aminotransferase activity. Coupling of alanine aminotransferase with glutamate dehydrogenase was ascertained by Kengen and Stams (8). Whether this mechanism is operational in members of the 
Thermotogales has yet to be investigated. It is known that glutamate dehydrogenase is the key enzyme which links the carbon and nitrogen metabolic pathways in $P$. furiosus during carbohydrate fermentation (17). It is possible that a similar situation exists in all members of the Thermotogales; this is worthy of further investigation. L-Alanine production from sugar fermentation has been reported for the intestinal parasite Giardia lamblia (5), the genetically modified bacterium Zymomonas mobilis (22), and more recently a moderately thermophilic Clostridium species (13). On the basis of our report, it can be proposed that L-alanine production from sugar fermentation may be more widespread among the three domains of bacteria than previously believed.

Nucleotide sequence accession number. The $16 \mathrm{~S}$ rRNA sequence for $F$. gondwanense $\mathrm{AB} 39^{\mathrm{T}}$ has been deposited in the EMBL database under accession number Z49117.

We thank P. Roger, J. L. Cayol, and G. Loison for helpful discussions and N. Zylber, BIP-CNRS, for analyzing amino acids.

Funding in part from the Australian Research Council to B.K.C.P. and from Elf Aquitaine to G.R. is gratefully acknowledged.

\section{REFERENCES}

1. Adams, M. W. W. 1990. The metabolism of hydrogen by extremely thermophilic, sulfur-dependent bacteria. FEMS Microbiol. Rev. 75:219-238.

2. Andrews, K. T., and B. K. C. Patel. 1996. Fervidobacterium gondwanense sp. nov., a new thermophilic anaerobic bacterium isolated from nonvolcanically heated geothermal waters of the Great Artesian Basin of Australia. Int. J. Syst. Bacteriol. 46:265-269.

3. Bonch-Osmolovskaya, E. A. 1994. Bacterial sulfur reduction in hot vents. FEMS Microbiol. Rev. 15:65-77.

4. Darimont, B., and R. Sterner. 1994. Sequence, assembly and evolution of a primordial ferredoxin from Thermotoga maritima. EMBO J. 13:1772-1781.

5. Edwards, R., F. V. Gilroy, M. B. Jimenez, and W. J. O'Sullivan. 1989. Alanine as a major end product of metabolism by Giardia lamblia: a proton nuclear magnetic resonance study. Mol. Biochem. Parasitol. 37:19-26.

6. Hüber, R., C. R. Woese, T. A. Langworthy, J. K. Kristjansson, and K. O. Stetter. 1990. Fervidobacterium islandicum sp. nov., a new extremely thermophilic eubacterium belonging to the "Thermotogales." Arch. Microbiol. 154:105-111.

7. Kengen, S. W. M., F. A. M. de Bok, N. D. Van Loo, C. Dijkema, A. J. M. Stams, and W. M. de Vos. 1995. Evidence for the operation of a novel Embden-Meyerhof pathway that involves ADP-dependent kinases during sugar fermentation by Pyrococcus furiosus. J. Biol. Chem. 269:17537-17541.
8. Kengen, S. W. M., and A. J. M. Stams. 1994. Formation of L-alanine as a reduced end product in carbohydrate fermentation by the hyperthermophilic archaeon Pyrococcus furiosus. Arch. Microbiol. 161:168-175.

9. Kobayashi, T., S. Higuchi, K. Kimura, T. Kudo, and K. Horikoshi. 1995. Properties of glutamate dehydrogenase and its involvement in alanine production in a hyperthermophilic archaeon, Thermococcus profundus. J. Biochem. 118:587-592.

10. L'Haridon, S., A. L. Reysenbach, P. Glénat, D. Prieur, and C. Jeanthon. 1995. Hot subterranean biosphere in a continental oil reservoir. Nature (London) 377:223-224.

11. Lowe, S. E., M. K. Jain, and J. G. Zeikus. 1993. Biology, ecology, and biotechnological applications of anaerobic bacteria adapted to environmental stresses in temperature, $\mathrm{pH}$, salinity, or substrates. Microbiol. Rev. 57: 451-509.

12. Moore, S., D. H. Spackman, and W. H. Stein. 1958. Chromatography of amino acids on sulfonated polystyrene resins: an improved system. Anal. Chem. 30:1185-1190.

13. Örlygsson, J., R. Anderson, and B. H. Svensson. 1995. Alanine as an end product during fermentation of monosaccharides by Clostridium strain P2. Antonie Leeuwenhoek 68:273-280.

14. Patel, B. K. C., H. W. Morgan, and R. M. Daniel. 1985. Fervidobacterium nodosum gen. nov. and spec. nov., a new chemoorganotrophic, caldoactive, anaerobic bacterium. Arch. Microbiol. 141:63-69.

15. Ravot, G., M. Magot, M.-L. Fardeau, B. K. C. Patel, G. Prensier, A. Egan, J.-L. Garcia, and B. Ollivier. 1995. Thermotoga elfii sp. nov., a novel thermophilic bacterium from an African oil-producing well. Int. J. Syst. Bacteriol. 45:308-314.

16. Ravot, G., B. Ollivier, M. Magot, B. K. C. Patel, J.-L. Crolet, M.-L. Fardeau, and J.-L. Garcia. 1995. Thiosulfate reduction, an important physiological feature shared by members of the order Thermotogales. Appl. Environ. Microbiol. 61:2053-2055.

17. Robb, F. T., J. B. Park, and M. W. W. Adams. 1992. Characterization of an extremely thermostable glutamate dehydrogenase: a key enzyme in the primary metabolism of the hyperthermophilic archaebacterium Pyrococcus furiosus. Biochim. Biophys. Acta 1120:267-272.

18. Schauder, R., and A. Kröger. 1993. Bacterial sulfur respiration. Arch. Microbiol. 159:491-497.

19. Schröder, C., M. Selig, and P. Schönheit. 1994. Glucose fermentation to acetate, $\mathrm{CO}_{2}$ and $\mathrm{H}_{2}$ in the anaerobic hyperthermophilic eubacterium Thermotoga maritima: involvement of the Embden-Meyerhof pathway. Arch. Microbiol. 161:460-470.

20. Stetter, K. O. 1995. Microbial life in hyperthermal environments. ASM News 61:285-290.

21. Stetter, K. O., R. Hüber, E. Blochl, M. Kurr, R. D. Eden, M. Fielder, H. Cash, and L. Vance. 1993. Hyperthermophilic Archaea are thriving in deep North Sea and Alaskan reservoirs. Nature (London) 365:743-745.

22. Uhlenbusch, I., H. Sahm, and G. A. Sprenger. 1991. Expression of an Lalanine dehydrogenase gene in Zymomonas mobilis and excretion of $\mathrm{L}$ alanine. Appl. Environ. Microbiol. 57:1360-1366. 